\title{
Redescription of some species of Bryozoa described by J. Jullien and L. Calvet in the NE Atlantic
}

\author{
Oscar REVERTER-GIL ${ }^{1, *} \&$ Javier SOUTO ${ }^{1,2}$ \\ ${ }^{1}$ Departamento de Zooloxía e Antropoloxía Física, Facultade de Bioloxía, \\ Universidade de Santiago de Compostela, 15782 Santiago de Compostela, Spain. \\ ${ }^{2}$ Institut für Paläontologie, Fakultät für Geowissenschaften, Geographie und Astronomie, \\ Geozentrum, Universität Wien, Althanstrasse 14, 1090 Vienna, Austria. \\ *Corresponding author: oscar.reverter@usc.es \\ ${ }^{2}$ Email: javier.souto@usc.es \\ * urn:Isid:zoobank.org:author:001DFC48-0F01-43AF-90EC-452BE6954DDF \\ ${ }^{2}$ urn:lsid:zoobank.org:author:E14FC8A9-40B5-4BF6-8551-3F2A1D991463
}

\begin{abstract}
Five species described by Jullien and/or Calvet from the NE Atlantic are redescribed and stabilized by typification: Hippothoa amoena, Schizoporella confusa, S. jullieni, S. ovum and Smittia guernei. Three new synonymies are established: Schizoporella jullieni with Hippothoa amoena, S. ovum with Escharina alderi, and Escharella pseudopunctata with Smittia guernei. A new trypostegid genus, Pulpeirina gen. nov., is erected for H. amoena. Three new combinations are introduced.
\end{abstract}

Keywords. Azores, Iberian Peninsula, Strait of Gibraltar, new genus, Trypostegidae.

Reverter-Gil O. \& Souto J. 2015. Redescription of some species of Bryozoa described by J. Jullien and L. Calvet in the NE Atlantic. European Journal of Taxonomy 157: 1-17. http://dx.doi.org/10.5852/ejt.2015.157

\section{Introduction}

Towards the end of the nineteenth century several oceanographic expeditions by the research vessels Travailleur, l'Hirondelle and Talisman collected samples in the Northeast Atlantic. The resulting bryozoan studies were published by Jullien $(1882,1883)$, Jullien \& Calvet (1903) and Calvet (1906a, 1906b, 1907). In total, about 135 new species were described in these papers, but most of them have not subsequently been redescribed according to current standards. Therefore, it is necessary to give accurate new descriptions, based on the original material and SEM examinations, of the species described by J. Jullien and/or L. Calvet, a task that has recently been started by various authors (e.g., Reverter-Gil \& Fernández-Pulpeiro 1999, 2005; Reverter-Gil et al. 2011, 2015; Souto et al. 2011; Berning 2013).

In the present paper we redescribe five further species, which are stabilized by typification. The goal is to provide a better understanding of these species so as to ensure easier future identification and to give a clearer appreciation of their taxonomic affinities. Lectotypes have been selected from the original syntypes, three new synonymies are established and three new combinations are introduced. A new trypostegid genus is erected for one of the redescribed species. 


\section{Material and Methods}

Types and other material stored in the following museums have been studied: Muséum national d'Histoire naturelle, Paris (MNHN), Musée Océanographique, Monaco (MOM) and the Natural History Museum, London (NHMUK).

The longitudes of the sampling stations of the Travailleur, Talisman and l'Hirondelle cruises, published by Jullien (1882, 1883), Jullien \& Calvet (1903) and Calvet (1906a, 1906b, 1907), were initially measured with reference to the Paris meridian. They have here been corrected to the Greenwich meridian (see Ryland 1969: 238).

The samples were examined with a stereo microscope and uncoated material was photographed with Zeiss EVO LS15 and Inspect S50 scanning electron microscopes, with a back-scattered electron detector in low variable vacuum mode. Measurements were taken with the software Image ${ }^{\circledR}$ on SEM photographs.

\section{Results}

Order Cheilostomata Busk, 1852

Infraorder Ascophorina Levinsen, 1909

Superfamily Hippothooidea Busk, 1859

Family Trypostegidae Gordon, Tilbrook \& Winston in Winston, 2005

Genus Pulpeirina gen. nov. urn:1sid:zoobank.org:act:50502833-8EFA-4F91-ACE2-6831A613CECC

\section{Diagnosis}

Colony encrusting. Frontal wall gymnocystal, perforated by tubular pseudopores prolonged by subhorizontal tubules, arranged radially. Orifice sinuate. Suboral vestigial costae fused in saggital plane, leaving a narrow slit and a small central pore. Oral spines absent. Communication via small, basal porechambers. Ovicell globular, evenly perforated by small, tubular pores. Orifice dimorphic, closed by zooidal operculum. Zooeciules and avicularia absent.

\section{Type species}

Hippothoa amoena Jullien \& Calvet, 1903.

\section{Etymology}

This genus is dedicated to Dr. Eugenio Fernández-Pulpeiro, who died in September 2014. He was one of the people responsible for restarting bryozoology in Spain, but also our director, colleague and friend, and above all our best example as a researcher as well as a person. Gender feminine.

Pulpeirina amoena (Jullien \& Calvet, 1903) comb. nov.

Figs 1A-E, 2A-E, 3A-E; Table 1

Hippothoa amoena Jullien \& Calvet, 1903: 88, pl. 10, fig. 9.

Schizoporella jullieni Calvet in Jullien \& Calvet, 1903: 142, pl. 17, figs 1a-b.

? Smittia guernei Jullien \& Calvet, 1903: 103 pars.

? Hippothoa amcena - Calvet 1907: 424. — d'Hondt, 1975: 579. 


\section{Material examined}

Lectotype of Hippothoa amoena (here designated)

AZORES: Hirondelle st. 247, Pico Island, 38²4' N, 2801'26” W, 30 Aug. 1888, 318 m (MOM INV22578).

\section{Paralectotypes of Hippothoa amoena}

AZORES: Hirondelle st. 226, Pico-Faial Channel, 38³1'19" N, 28³4'31' W, 14 Aug. 1888, 130 m (MOM INV-22579, MOM INV-22581).

Lectotype of Schizoporella jullieni (here designated)

AZORES: Hirondelle st. 226, Pico-Faial Channel, 38³1'19" N, 28³4'31' W, 14 Aug. 1888, 130 m (MOM INV-22502).

\section{Paralectotypes of Schizoporella jullieni}

AZORES: same data as lectotype, several small fragments covered with glue (MOM INV-22523); same data as lectotype, an encrusting colony, together with Chorizopora sp. and Hippothoa sp. (MOM INV22524).

\section{Other material examined}

SPAIN: Hirondelle st. 56, 4338’30" N, 608'16" W, N Iberian Peninsula, 4 Aug. 1886, 90 m, Jullien coll., originally labeled as "Smittia deguernei J. Jullien" (MOM INV-22580).
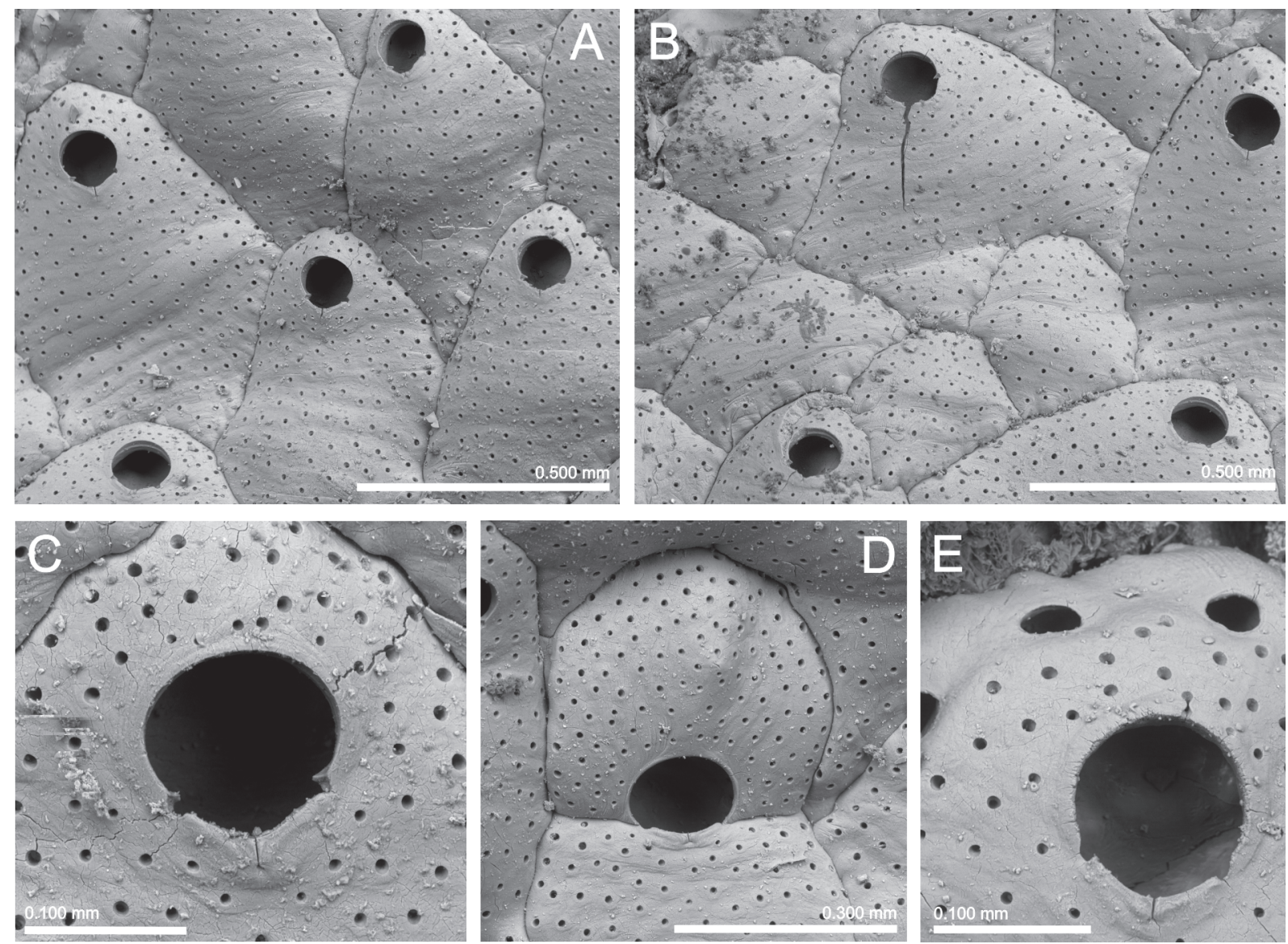

Fig. 1. Lectotype of Hippothoa amoena Jullien \& Calvet, 1903 (MOM INV-22578). A. Some autozooids. B. Group of irregular kenozooids. C. Primary orifice. D. Ovicell. E. Distal dietella. 


\section{Description}

Colony encrusting, unilaminar. Autozooids oval to hexagonal, only slightly convex, separated by shallow grooves. Frontal wall smooth, translucent in young zooids, marked with slight transversal undulations; perforated by numerous, evenly spaced, small pseudopores rimmed in surface, prolongated in oblique tubules. One to several rows of pores distal to zooidal orifice. Pores joined by short tubules, visible in transparent walls, forming somewhat radial series running to margins of zooid. Orifice cleithridiate, not terminal; anter transversely oval, surrounded by thin rim; separated from shallow, concave poster by short, pointed condyles and pair of small notches. Edge of poster formed by pair of presumed vestigial costae fused in saggital plane, leaving small central pore and narrow slit. Spines absent. Communication via small, basal pore chambers. Ovicells terminal, prominent, cleithral. Large ooecium formed by distal kenozooid with no visible frontal part (Ostrovsky et al. 2009; Ostrovsky 2013). Ectooecium smooth, evenly perforated by small pseudopores prolongated in tubules, with small central umbo and sometimes growth lines. Ovicell aperture dimorphic, larger than in infertile autozooids, formed by proximal border of ooecium and poster of zooidal orifice; closed by zooidal operculum. Small, irregularly shaped kenozooids (without any orifice) may be present filling small spaces between autozooids. Zooeciules and avicularia absent. Ancestrula not observed.
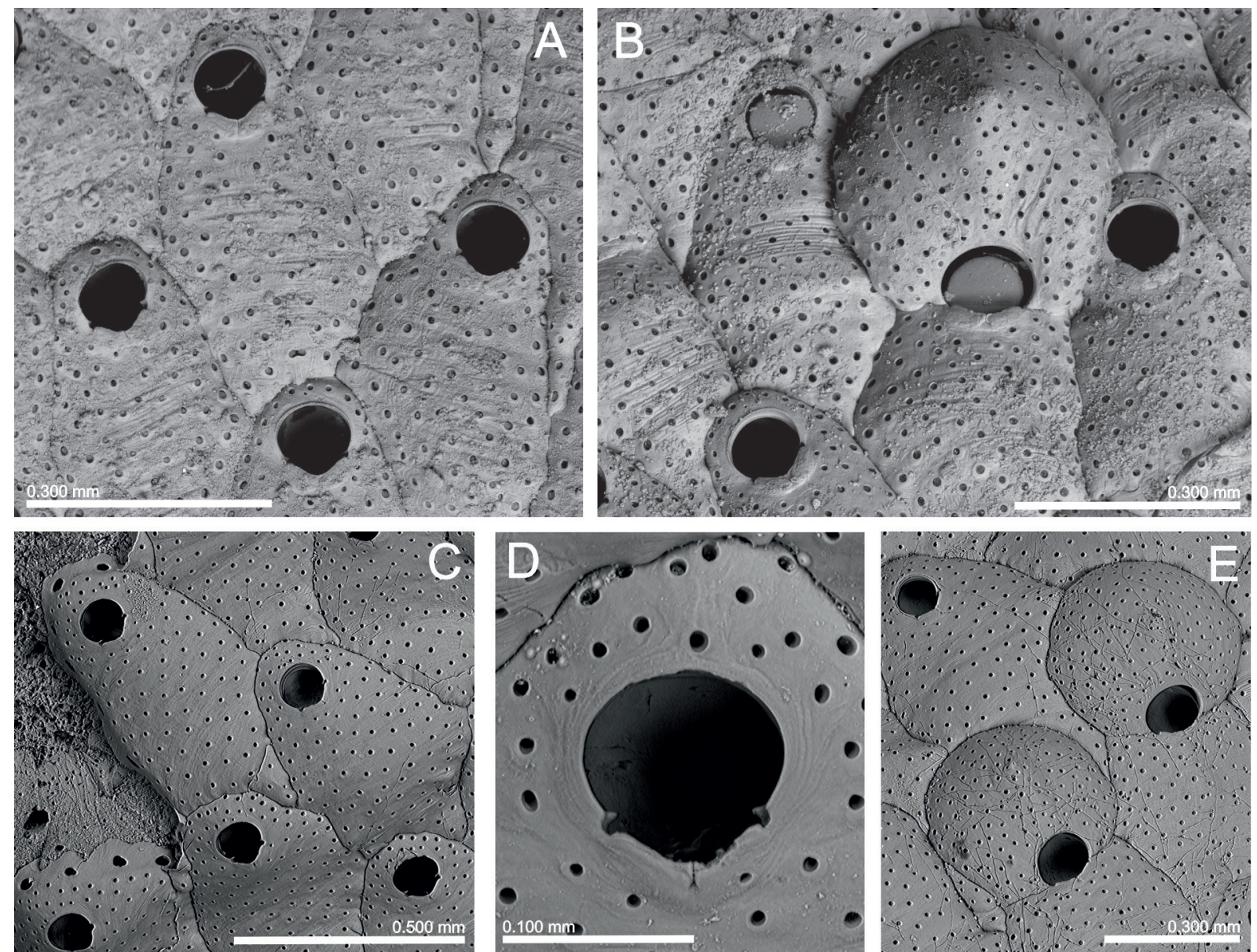

Fig. 2. Pulpeirina amoena (Jullien \& Calvet, 1903) comb. nov. A. Autozooids (MOM INV-22502, lectotype of Schizoporella jullieni Calvet in Jullien \& Calvet, 1903). B. Same, ovicellate and nonovicellate zooids. C. Autozooids; note the distal dietella (MOM INV-22580). D. Same, primary orifice. E. Same, ovicells. 
Table 1. Measurements (in mm) of Pulpeirina amoena (Jullien \& Calvet, 1903) comb. nov. (lectotypes and paralectotypes). $\mathrm{SD}=$ standard deviation; $\mathrm{N}=$ number of measurements.

\begin{tabular}{lccccc}
\hline & Mean & SD & Minimum & Maximum & N \\
\hline Autozooid length & 0.626 & 0.1024 & 0.463 & 0.797 & 41 \\
Autozooid width & 0.399 & 0.1172 & 0.244 & 0.670 & 41 \\
Orifice length & 0.096 & 0.0105 & 0.080 & 0.117 & 41 \\
Orifice width & 0.101 & 0.0099 & 0.082 & 0.127 & 41 \\
Ovicell orifice length & 0.102 & 0.0065 & 0.096 & 0.110 & 5 \\
Ovicell orifice width & 0.132 & 0.0100 & 0.121 & 0.148 & 5 \\
Ooecium length & 0.293 & 0.0191 & 0.270 & 0.330 & 7 \\
Ooecium width & 0.360 & 0.0334 & 0.309 & 0.394 & 7 \\
\hline
\end{tabular}

\section{Remarks}

Hippothoa amoena was described by Jullien \& Calvet (1903) for three samples collected on shells at two stations near Pico Island, Azores, at depths between 130 and $318 \mathrm{~m}$. The original material is now kept at MOM and a lectotype is designated here. The name of the species appeared in the original paper with two different spellings: 'amœna' and 'amæna'. Both include a ligature and are therefore incorrect according to Art. 32.5.2 of the ICZN Code (ICZN 1999). We select here the first spelling and correct it to amoena (Arts 19.3, 24.2.3 and 32). Hippothoa amoena was later reported from its original area between 80 and $115 \mathrm{~m}$ by Calvet (1907) and by d'Hondt (1975) between 80 and $1260 \mathrm{~m}$, but this material was not found in MNHN or MOM, so perhaps it has been lost.

Schizoporella jullieni was described by Calvet (Jullien \& Calvet 1903), also from material collected at the Azores (strait between Pico and Faial Islands, at a depth of $130 \mathrm{~m}$ ). The original material is also kept at MOM and a lectotype is designated here. Schizoporella jullieni does not seem to have been reported since its original description. However, Gautier (1962: 121) stated that $S$. jullieni must be a synonym of Trypostega claviculata (Hincks, 1884), a species that he reported from the Strait of Sicily. This synonymy was subsequently assumed by Arístegui Ruiz (1984) when citing T. claviculata from the Canary Islands. These records differ from $S$. jullieni in the presence of interzooidal avicularia and the absence of the vestigial suboral costae. A revision of Gautier's original material proves that it belongs to a new species of Trypostega, which will be described in a future paper.

A revision of the type material of $H$. amoena and $S$. jullieni demonstrated that they correspond to the same species. Taking into account that $H$. amoena was described first in the original paper, and reported twice since its original description, we decide here to give precedence to this name, according to Art. 24 of the ICZN Code.

The porous gymnocystal frontal wall, the suboral pair of vestigial costae, and the absence of oral spines in H. amoena are all characters reminiscent of those in several taxa, such as the recently described genus Vitrimurella Winston et al., 2014, some fossil Trypostegidae, or even some Catenicellidae Busk, 1852. However, catenicellids differ most obviously by their erect, flexible and jointed colonies. Vitrimurella differs, among other features, by the ovicell. In the type species of the genus, V. lata (Smitt, 1873), and two other species, the ovicell is small, cap-like, immersed in the distal part of the maternal zooid, and therefore quite different from the large, prominent and uniformly perforated ovicell of H. amoena. In two other species of the same genus, V. gemina (Tilbrook, 2006) and V. lepida (Hayward, 1988), the ooecia are also prominent but possess a median suture, perhaps suggesting that they belong in a different 
genus. Hippothoa amoena also differs from fossil Trypostegidae provided with suboral vestigial costae (e.g., Trilophora Lang, 1916, Boreasina Voigt \& Hillmer, 1983 and Grammothoa Voigt \& Hillmer, 1983) mainly by the absence of zooeciules or avicularia and the dimorphic orifices. Finally, Boreas Morris, 1980 also lacks avicularia, as H. amoena, but it lacks suboral vestigial costae and dimorphic orifices.

Moreover, H. amoena differs from all these taxa by the pseudopores of the frontal wall, which are not simple perforations, as can be seen in young, translucent zooids. The perforations in the surface of the zooids are formed during the calcification of the frontal wall (Fig. 3A). As the calcified layer thickens, the pseudopores extend to form short, oblique tubules. Groups of these oblique tubules are joined together by basal, horizontal tubules arranged forming a somewhat radial series, presumably reaching the zooidal margins (Fig. 3B, E). In some cases there is also a median, longitudinal horizontal tubule (Fig. 3C). The ovicells, however, do not possess horizontal tubules. The horizontal tubules do not seem to actually be excavated in the calcified layer, but rather to be an open space between the calcified layer and the underlying membranous ectocyst (Fig. 3D). If this is the case, this space represents a vestigial hypostegal coelom. This possibility, together with the radial arrangement of the horizontal tubules
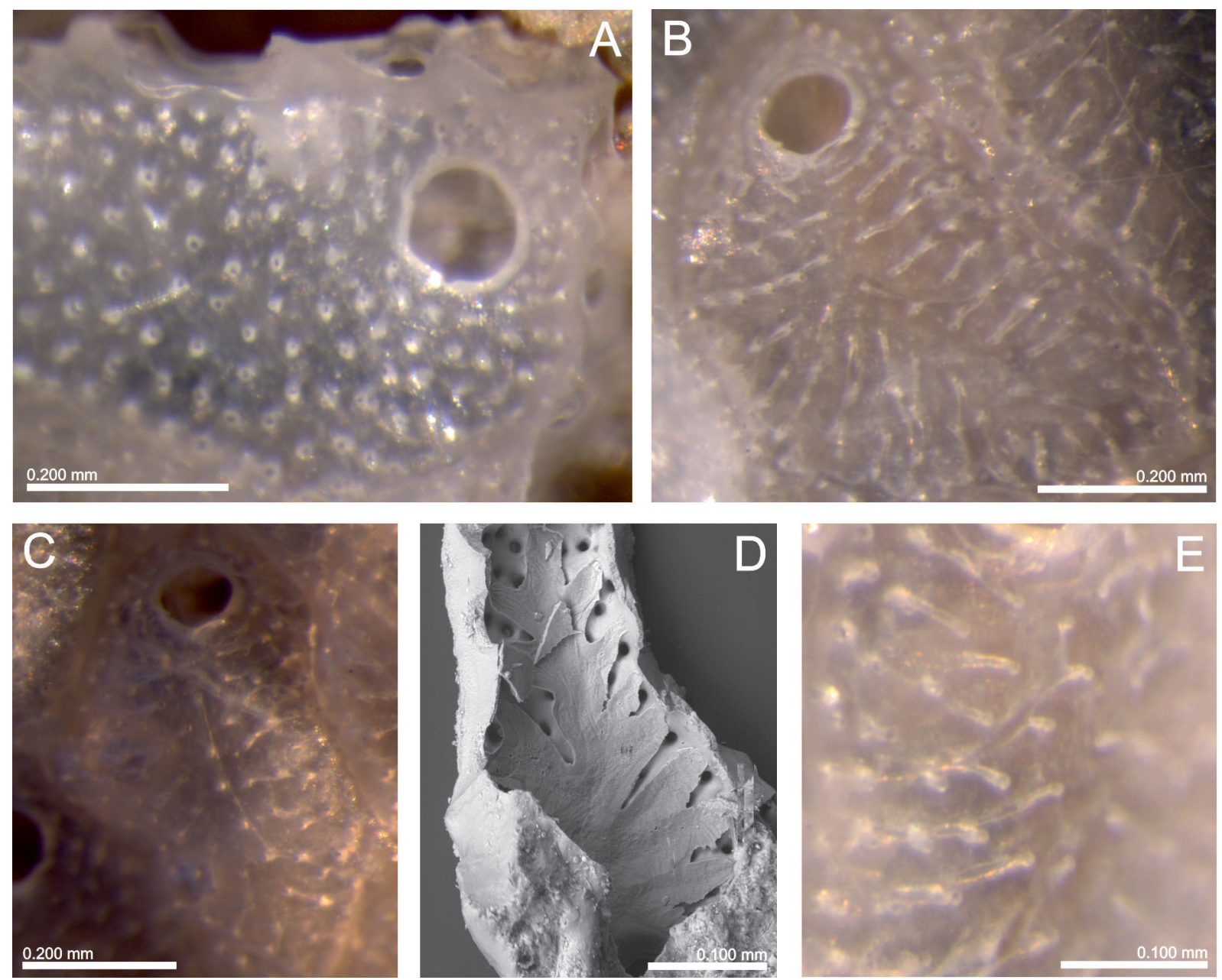

Fig. 3. Pulpeirina amoena (Jullien \& Calvet, 1903) comb. nov. (MOM INV-22580). A. Simple pores in a young, marginal autozooid. B. Tubular pores arranged radially. C. An autozooid with radially arranged tubular pores and a medial horizontal tubule. D. Inner view of an autozooid showing the tubular pseudopores and horizontal tubules. E. Detail showing tubular pores joining the horizontal tubule. 
and the pair of suboral vestigial costae, is perhaps reminiscent of an ancient spinocystal frontal shield. Nevertheless, study of more fresh material is necessary to clearly establish the structure of the frontal wall in H. amoena. Although some related species may have tubular pseudopores (e.g., Trypostega sp. nov. or Vitrimurella spp., L.M. Viera pers. comm. Sep. 2014), they are not radially arranged. On the other hand, it will be difficult to prove whether fossil Trypostegidae had radial tubular pseudopores.

Therefore, we erect a new genus, Pulpeirina, for H. amoena, and we tentatively place it in the family Trypostegidae. The structure of the frontal wall in Pulpeirina amoena comb. nov., perhaps reminiscent of an ancient spinocystal frontal wall, may support the suggestion that the Trypostegidae evolved from a pliophloeine ancestor (Gordon 2000).

Pulpeirina amoena comb. nov. is only known with certainty from around Pico Island, Azores, between 80 and $318 \mathrm{~m}$ depth (up to $1260 \mathrm{~m}$ according to d'Hondt 1975). However, we have found another sample, labeled as Smittia deguernei and presumably collected from the NW Iberian Peninsula, which corresponds to the same species. Smittia guernei was described by Jullien \& Calvet (1903) for two samples collected off the NW coast of the Iberian Peninsula at a depth of $90 \mathrm{~m}$. One of the samples (MOM INV-22518) matches the original description and is here designated as the lectotype of the species (see below). The other sample (MOM INV-22580) corresponds to P. amoena comb. nov. (see Fig. 3). Taking into account the evident differences between both species, it seems impossible that Jullien, who originally described both of them in the same paper (or even any other researcher), could have made such a mistake of identification. It seems more probable that the samples were mixed up during their preservation or during their subsequent revision by Calvet, when he undertook the responsibility of finishing the study of the samples collected by the Hirondelle. Therefore, we consider that the geographical origin of this sample of P. amoena comb. nov. is also doubtful.

\section{Superfamily Schizoporelloidea Jullien, 1882 \\ Family Escharinidae Tilbrook, 2006}

Genus Escharina Milne Edwards, 1836

Escharina alderi (Busk, 1856)

Figs 4A-E, 5A-E; Table 2

Alysidota alderi Busk, 1856: 311, pl. 9, figs 6-7.

? Lepralia barleei Busk, 1860: 143, pl. 26, figs 1-2.

Schizoporella ovum Jullien, 1882: 16, pl. 15, figs 36-37.

Schizoporella alderi - Hincks 1880: 243, pl. 36, figs 9, 9a, 10.

Schizoporella ovum - Jullien 1883: 512, pl. 15, figs 36-37. — Calvet 1907: 422.

Escharina alderi - Hayward \& Ryland 1999: 228, figs 94c-d; 96.

Schizomavella ovum - Reverter-Gil \& Fernández-Pulpeiro 2001: 120.

\section{Material examined}

Lectotype of Schizoporella ovum (here designated)

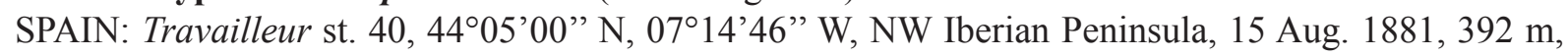
Jullien coll., one colony on a shell, figured specimen (NHMUK 1899.7.1.2348).

\section{Paralectotypes of Schizoporella ovum}

SPAIN: same data as lectotype (MNHN 1025, MNHN 2347). 


\section{Other material examined}

NORWAY: Alysidota alderi, Busk coll., one uniserial colony, with some avicularia but no ovicell, on a shell (NHMUK 1899.7.1.2143).

UNITED KINGDOM: Alysidota alderi, Shetland, 1859, Busk coll., paratype (NHMUK 1899.7.1.2144); Alysidota alderi, Shetland, 1859, Busk coll., type (NHMUK 1899.7.1.2145); Escharina alderi var. barleii, Shetland, Busk coll., marked as 'Type?' (NHMUK 1911.10.1.1197); Escharina alderi, Scotland, 22 Oct. 1958, st. 12, 52 m, Ryland coll. (NHMUK 1994.3.14.8).

LOCALITY UNKNOWN: Schizoporella ovum, Talisman 1883, 340 m, no further data, Calvet coll. (MNHN 3770).

\section{Description}

Colony encrusting, composed of linear series of autozooids, or unilaminar, multiserial. Autozooids oval to hexagonal, separated by sutures. Frontal shield convex, granular, uniformely perforated by some 25 small rounded pores, often inconspicuous, plus a row of small marginal pores. Distolateral vertical walls with several dietella. Primary orifice as long as wide. Inner distolateral orifice rim with immersed,
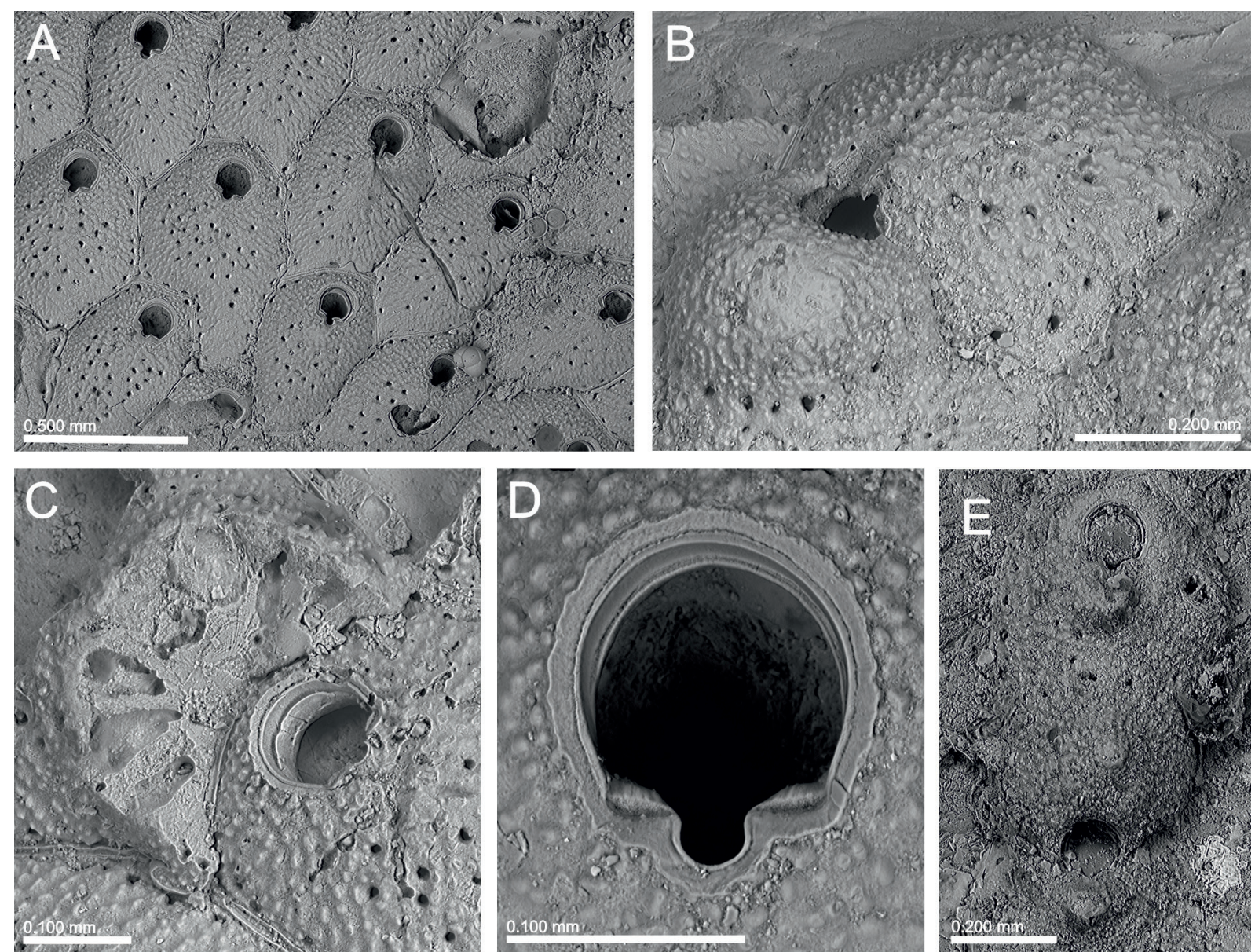

Fig. 4. Escharina alderi (Busk, 1856). A. Group of autozooids (NHMUK 1911.10.1.1197, type of Alysidota alderi Busk, 1856). B. Same, ovicellate zooid; note the distal marginal pores in the ovicell. C. Same, detail of a broken ovicell. D. Same, primary orifice. E. Ovicellate zooid and one adventitious avicularium in a uniserial colony (NHMUK 1899.7.1.2145, paratype of Alysidota alderi Busk, 1856). 
Table 2. Measurements (in $\mathrm{mm}$ ) of Escherina alderi (Busk, 1856) (lectotype and paralectotypes of Schizoporella ovum Jullien, 1882). SD = standard deviation; $\mathrm{N}=$ number of measurements.

\begin{tabular}{lccccc}
\hline & Mean & SD & Minimum & Maximum & $\mathrm{N}$ \\
\hline Autozooid length & 0.640 & 0.0634 & 0.546 & 0.751 & 10 \\
Autozooid width & 0.442 & 0.0673 & 0.331 & 0.528 & 10 \\
Orifice length & 0.118 & 0.0083 & 0.106 & 0.130 & 10 \\
Orifice width & 0.119 & 0.0086 & 0.106 & 0.133 & 10 \\
Ooecium length & 0.260 & 0.0138 & 0.239 & 0.268 & 4 \\
Ooecium width & 0.297 & 0.0209 & 0.266 & 0.310 & 4 \\
\hline
\end{tabular}

very narrow shelf. Anter slightly horseshoe-shaped, proximal margin straight, with U-shaped sinus, as deep as wide, occupying one third of proximal border. Primary orifice encircled by smooth, broad band of gymnocystal calcification. Oral spines absent. A low, conical umbo may be developed proximal to sinus. Avicularia rare, lateral to orifice, sporadically present in uniserial colonies, apparently absent in multiserial colonies. Rostrum triangular, raised, directed proximally or proximo-laterally. Ovicell globular, recumbent on distal autozooid and partially covering orifice of maternal zooid. Surface granular, with single series of septular pores around basal periphery and sometimes raised into a central umbo. Ancestrula not observed.

\section{Remarks}

Busk (1856) described Alysidota alderi, a species with zooids in linear series, imperforate ovicells and rare adventitious avicularia. Some years later, he described Lepralia barleei for a single multiserial colony encrusting a shell collected in Shetland, with ovicells with peripheral pores and lacking avicularia (Busk 1860).

Norman (1869) was the first author who considered these two species to be synonymous while reporting A. alderi from Shetland at depths between 50 and 170 fathoms $(90-310 \mathrm{~m})$. He also stated that the type specimens of both species were in his collection. Hincks (1880) assumed this synonymy to be correct and transferred the species to the genus Schizoporella. Finally, Marcus (1940) transferred Schizoporella alderi to the genus Escharina. Type and other material labeled as A. alderi is conserved at the NHMUK, but no original material of $L$. barleei seems to exist. Although the sample NHMUK 1911.10.1.1197 is labeled as the type of 'Escharina alderi var. barleei', it contains two colonies on stones, so they do not match the original description of the species. As no original material of L. barleei is preserved and the original description is very vague, it is not possible at present to confirm or reject the proposed synonymy.

Schizoporella ovum was described by Jullien (1882) for an undeterminate number of dead multiserial specimens, with ovicells with peripheral pores and lacking avicularia, collected off the NW Iberian Peninsula at a depth of $392 \mathrm{~m}$. Three type specimens are now kept at NHMUK and MNHN; the one at NHMUK is here designated as the lectotype. Calvet (1907) reviewed the original record by Jullien, stating that the original material consisted of "trois échantillons sur coquilles". This author also reported two further colonies, also on shells, collected by the Talisman 1883 cruise from an unrecorded locality at a depth of $340 \mathrm{~m}$; this material (MNHN 3770), although belonging to the same species, is not part of the type series. Schizoporella ovum does not seem to have been rediscovered since then, but it was transferred to the genus Schizomavella by Reverter-Gil \& Fernández-Pulpeiro (2001) following their revision of the type material at Paris. 
The type material of Schizoporella ovum is identical to the sample NHMUK 1911.10.1.1197 ('Escharina alderi var. barleei'), so they belong to the same species. Furthermore, $S$. ovum may be somewhat similar to Lepralia barleei as originally described. On the other hand, the autozooids of $S$. ovum are identical to the autozooids of E. alderi (see Figs 4-5), as was stated by Hincks (1880: 244) for uniserial and multiserial colonies of $S$. alderi. Differences between these two species do not appear to be significant. Schizoporella ovum (and L. barleei) develop multiserial colonies, whereas Escharina alderi forms uniserial chains of zooids. According to Norman (1869), both forms of growth may even share the same substrate. In S. ovum (as in L. barleei) avicularia have not been reported, and in E. alderi they are rare. Therefore, their presence is perhaps related to the uniserial mode of growth, but in any case, their presence or absence should not be used to differentiate species. In E. alderi the development of a sporadic umbo in the ovicell and in the autozooids has been reported, while it is absent in the material of $S$. ovum. Its presence may be related to a different degree of calcification, with no phylogenetic significance. Finally, the ovicell was described as imperforate in E. alderi, while in S. ovum (and L. barleei) it has a series of septular pores around the basal periphery. However, SEM images of the type material of $E$. alderi demonstrate that the ovicell really has several basal pores (Fig. 4E), similar
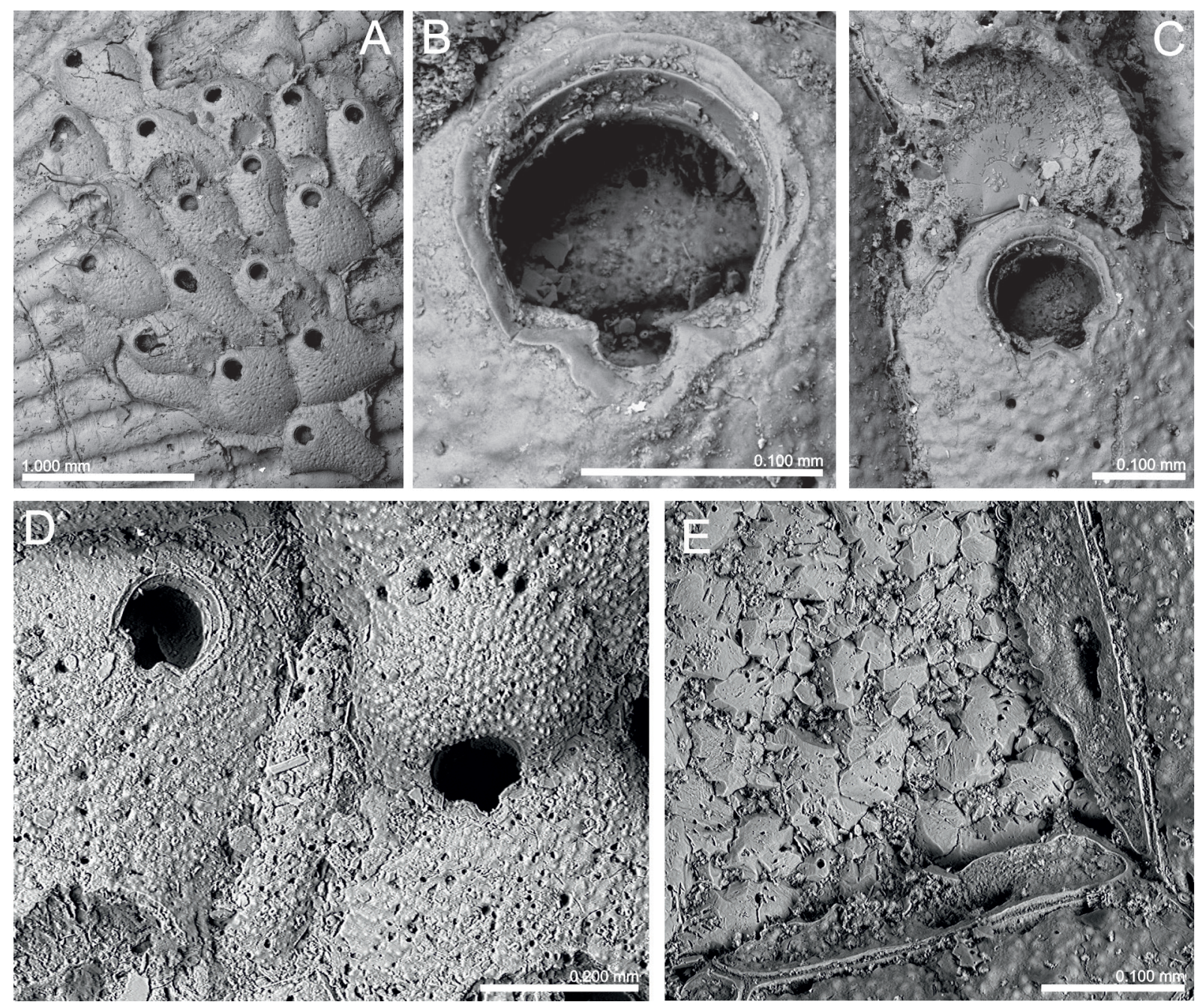

Fig. 5. Schizoporella ovum Jullien, 1882. A. Entire colony (NHMUK 1899.7.1.2348, lectotype). B. Same, primary orifice. C. Same, a broken ovicell showing the marginal pores. D. Ovicellate and nonovicellate zooids (MNHN 2347, paralectotype). E. Dietella (MNHN 1025, paralectotype). 
Table 3. Measurements (in mm) of Escharella guernei (Jullien \& Calvet, 1903) comb. nov. (lectotype). $\mathrm{SD}=$ standard deviation; $\mathrm{N}=$ number of measurements .

\begin{tabular}{lccccc}
\hline & Mean & SD & Minimum & Maximum & N \\
\hline Autozooid length & 0.499 & 0.0262 & 0.457 & 0.549 & 24 \\
Autozooid width & 0.361 & 0.0288 & 0.317 & 0.427 & 24 \\
Orifice length & 0.109 & 0.0046 & 0.096 & 0.117 & 24 \\
Orifice width & 0.098 & 0.0050 & 0.088 & 0.107 & 24 \\
Ooecium length & 0.242 & 0.0057 & 0.238 & 0.246 & 2 \\
Ooecium width & 0.275 & 0.0014 & 0.274 & 0.276 & 2 \\
\hline
\end{tabular}

to those present in the types of S. ovum (Fig. 5D). It should be stated that in the genus Escharina, as in all members of the family Escharinidae, the ovicell has been described as imperforate (see Hayward \& Ryland 1999; Tilbrook 2006), but the pores in the ovicell of E. alderi, as well as in other species of the family (see Bock 2014), indicate that the diagnosis of the family should be amended.

In conclusion, we propose here that Schizoporella ovum (and probably also Lepralia barleei) are junior synonyms of Escharina alderi, differing mainly in their mode of growth.

Superfamily Lepralielloidea Vigneaux, 1949

Family Romancheinidae Jullien, 1888

Genus Escharella Gray, 1848

Escharella guernei (Jullien \& Calvet, 1903) comb. nov.

Fig. 6A-D; Table 3

Smittia guernei Jullien \& Calvet, 1903: 103, pl. 13, fig. 1.

Escharella pseudopunctata Souto, Fernández-Pulpeiro \& Reverter-Gil, 2007: 368, figs 3-4.

? Mucronella peachi - d'Hondt 1974: 30 (not Johnston, 1847).

\section{Material Examined}

Lectotype of Smittia guernei (here designated)

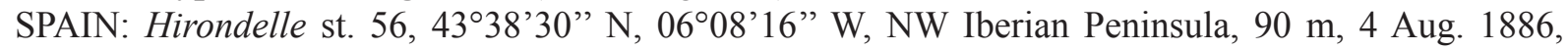
Jullien coll., originally labeled as "Smittia deguernei J. Jullien" (MOM INV-22518).

\section{Holotype of Escharella pseudopunctata}

FRANCE: English Channel, Pourquoi Pas? st. 101, Jun. 1914 (MNHN 20063).

Paratypes of Escharella pseudopunctata

FRANCE: same data as holotype (MNHN 20064).

\section{Other material examined}

SPAIN: Thalassa st. W403, 4356.2' N, 5039.3' W, Avilés Canyon, N Iberian Peninsula, 280-650 m, 10 Oct. 1970, det. d'Hondt, labeled as "Mucronella peachi (?)" (MNHN 7069); same data as preceding, species not marked on original label (MNHN 7070). 


\section{Diagnosis}

Colony encrusting unilaminar, multiserial. Zooids hexagonal to oval, with smooth, slightly convex frontal. Pores do not perforate, as tubules run from pores to margins of zooid. Secondary orifice campanulate. Primary orifice with small, quadrangular lyrula and small, rounded condyles. Six distal spines, retained in ovicellate zooids. Avicularia not present. Ovicell globular, recumbent on distal autozooid.

\section{Remarks}

Smittia guernei was described by Jullien \& Calvet (1903) for two samples collected off the NW coast of the Iberian Peninsula at a depth of $90 \mathrm{~m}$. In the collections of MOM there are two slides, labeled as types of $S$. deguernei [sic!], collected at the same station, but only one of them (MOM INV-22518) matches the original description and figure of the species, and it is therefore designated here as the lectotype. The other specimen (MOM INV-22580) corresponds to P. amoena comb. nov. (see above).
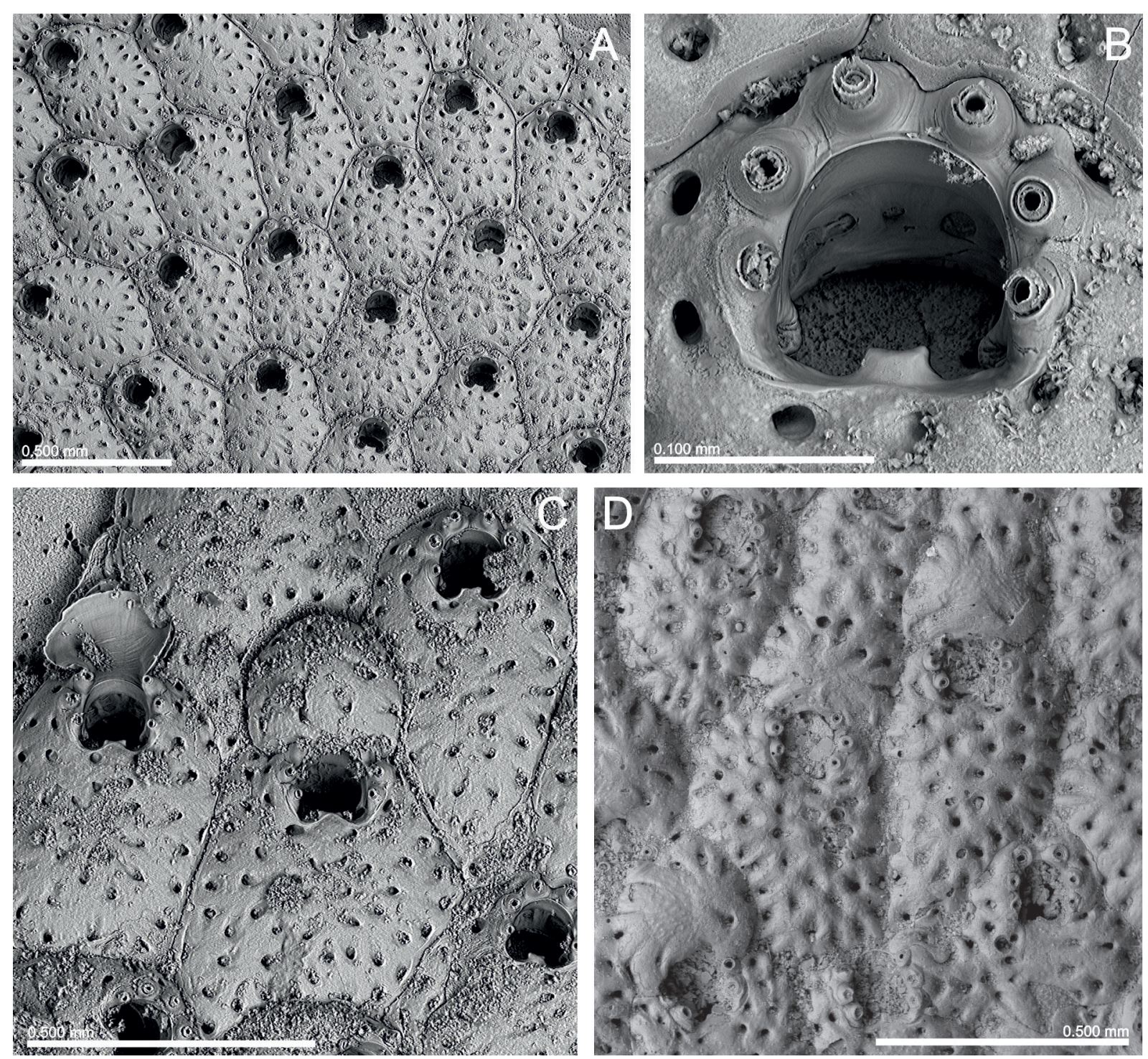

Fig. 6. Escharella guernei (Jullien \& Calvet, 1903) comb. nov. A. Autozooids (MOM INV-22518, lectotype). B. Same, primary orifice. C. Same, ovicellate zooids. D. Ovicellate and non-ovicellate zooids; note the ovicells, recumbent or immersed (MNHN 7069). 
Smittia guernei does not seem to have been reported under that name since its original description. Reverter-Gil \& Fernández-Pulpeiro (2001) reviewed the original record, without studying the original material, and stated that the species probably belongs in Escharella. The species was reported by d'Hondt (1974) as "Mucronella peachi ?" from a Thalassa locality at the Avilés Canyon, N Iberian Peninsula (see Material examined section).

Recently, Souto et al. (2007) described a new species, Escharella pseudopunctata, from material collected in the English Channel at an unrecorded depth. Examination of the lectotype of S. guernei reveals that E. pseudopunctata is actually a junior synonym. For a complete description of the species and further discussion of its generic assignment see Souto et al. (2007: 368-371).

There are some minor differences between the types of $S$. guernei and E. pseudopunctata. In the former, the ovicell is globular, recumbent on the distal autozooid (Fig. 6C), but in the latter the ovicell is almost entirely immersed in the distal autozooid (see Souto et al. 2007: fig. 4a, c). However, in the Thalassa material the ovicell may be recumbent or immersed in the same colony; this is rather frequent in several other genera of cheilostomatous Bryozoa (A. Ostrovsky, pers. comm. May 2015). Moreover, the secondary orifice seems more markedly bell-shaped in E. pseudopunctata (Fig. 6D; see also Souto et al. 2007: fig. 3d-e). Finally, zooids of E. pseudopunctata are slightly larger than those of S. guernei.

Escharella guernei comb. nov. was collected off the northern Iberian Peninsula at a depth of $90 \mathrm{~m}$ and at an unrecorded depth between 280 and $650 \mathrm{~m}$, as well as from an unrecorded locality in the English Channel.

Superfamily Celleporoidea Johnston, 1838

Family Phidoloporidae Gabb \& Horn, 1862

Genus Rhynchozoon Hincks, 1895

Rhynchozoon confusum (Calvet, 1906) comb. nov. Fig. 7A-E; Table 4

Schizoporella confusa Calvet, 1906b: 217.

Schizoporella confusa - Calvet 1907: 422, pl. 27, figs 12-13.

\section{Material Examined}

Lectotype (here designated)

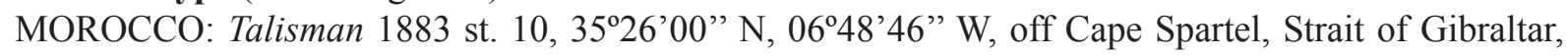
717 m, 10 Jun. 1883, Calvet coll., some fragments detached from a coral (MNHN 4007).

\section{Paralectotypes}

MOROCCO: same data as lectotype (MNHN 494, MNHN 1007, MNHN 1008, MNHN 2354).

\section{Description}

Colony encrusting, multilaminar, forming irregular crusts. Autozooids oval to irregularly polygonal, separated by very fine sutures on shallow grooves in young autozooids; boundaries becoming indistinct in later ontogeny. Frontal shield thick, finely granular, slightly convex, bordered by single series of marginal, round pores; rapidly covered by secondary calcification. Primary orifice orbicular to dropshaped, about as wide as long. Anter distinctly denticulate, with 16 to 25 rounded denticles. Proximal border almost occupied by shallow sinus flanked by two shoulders. Condyles small, inconspicuous, sloping towards sinus. No oral spines. Zooids rapidly developing a tuberculate peristome formed by 2 to 7 stout knobs, granular at apex but frequently broken in examined material; two lateral lobes most 
frequent and most developed; distal knobs may be absent or smaller. Some zooids may also have a single suboral umbo, smaller that the rest. One (occasionally two) avicularia present in most zooids, placed laterally, at midlength on zooidal margin and projecting beyond zooidal boundaries or lateral to orifice. Rostrum triangular, directed laterally or distolaterally; crossbar complete, without columella. Ovicells subimmersed, acleithral, with ectooecium formed by distal autozooid. Ectooecium covered by secondary calcification except smooth central area. Ovicell opening above zooidal orifice.

\section{Remarks}

Schizoporella confusa was described by Calvet (1906b; see also Calvet 1907) for several colonies growing on Lophohelia (=Lophelia) collected at a depth of 717 m near Cape Spartel (Strait of Gibraltar). The original material is now preserved at MNHN and we here designate a lectotype from that material. The species does not seem to have been recorded since its original description.

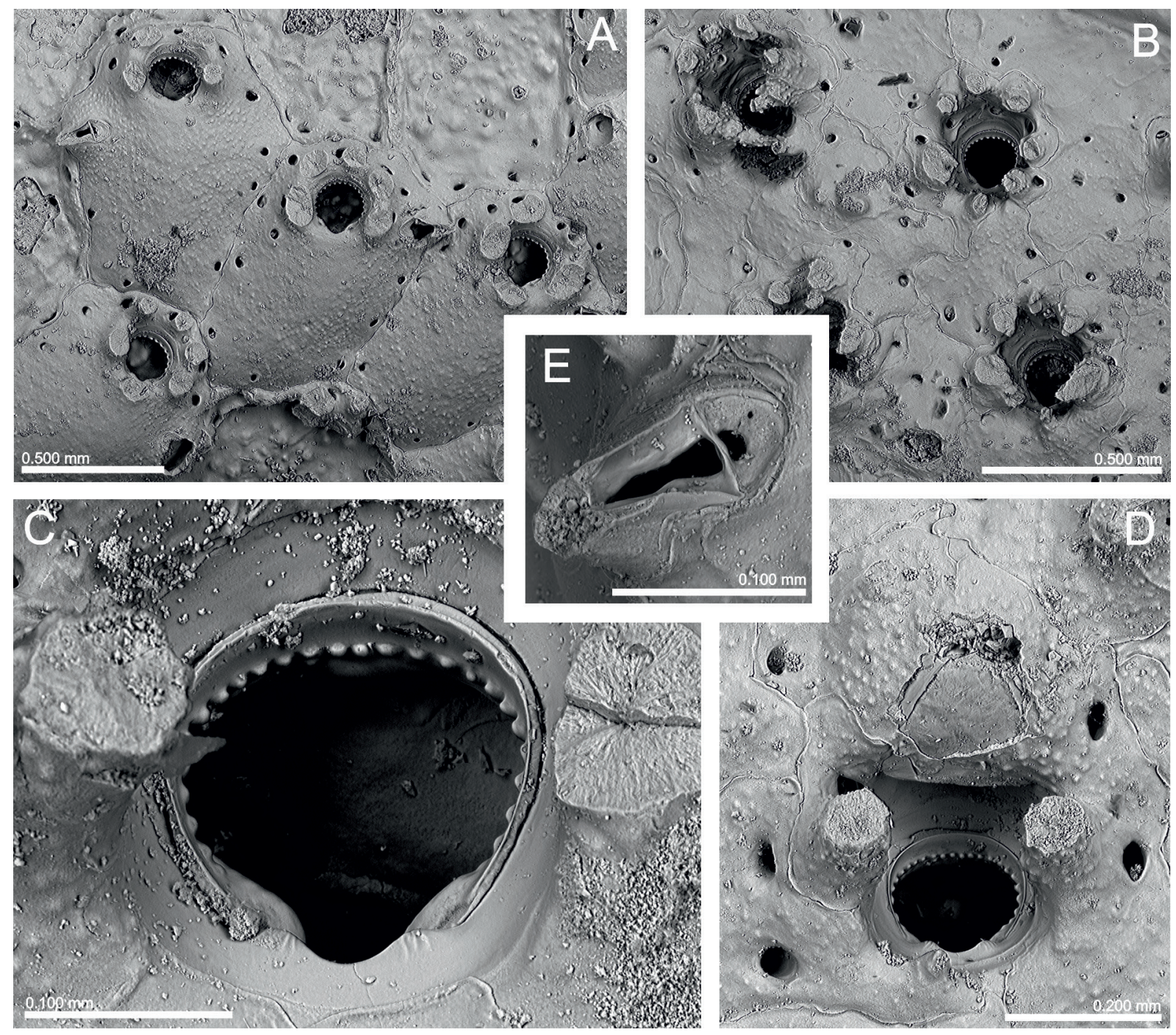

Fig. 7. Rhynchozoon confusum (Calvet, 1906) comb. nov. A. Young autozooids in the colony margin; note the presence of small adventitious avicularia (MNHN 2354, paralectotype). B. Older zooids with indistinct margins and well-developed oral knobs (MNHN 494, paralectotype). C. Primary orifice (MNHN 4007, lectotype). D. Same, ovicell. E. Detail of an adventitious avicularium (MNHN 494, paralectotype). 
Table 4. Measurements (in mm) of Rhynchozoon confusum (Calvet, 1906) comb. nov. (lectotype and paralectotypes). $\mathrm{SD}=$ standard deviation; $\mathrm{N}=$ number of measurements.

\begin{tabular}{lccccc}
\hline & Mean & SD & Minimum & Maximum & $\mathrm{N}$ \\
\hline Autozooid length & 0.883 & 0.1488 & 0.703 & 1.000 & 11 \\
Autozooid width & 0.681 & 0.0494 & 0.611 & 0.785 & 11 \\
Orifice length & 0.157 & 0.0130 & 0.143 & 0.179 & 11 \\
Orifice width & 0.162 & 0.0134 & 0.138 & 0.181 & 11 \\
Ovicell length & - & - & 0.341 & 0.344 & 2 \\
Ovicell width & - & - & 0.321 & 0.340 & 2 \\
Avicularium length & 0.168 & 0.0214 & 0.131 & 0.193 & 7 \\
Avicularium width & 0.067 & 0.0086 & 0.056 & 0.078 & 7 \\
\hline
\end{tabular}

The encrusting colonies, the zooids having only marginal pores, the distally denticulate orifice, with sinus and condyles, the well-developed peristome, the adventitious avicularia, and the ovicell with an exposed area of endooecium are all characters allowing the inclusion of the species in the genus Rhynchozoon Hincks, 1895. Rhynchozoon confusum comb. nov. is characterized by the tuberculate peristome formed by 2 to 7 stout knobs, the lack of a suboral avicularium, and the lateral, triangular avicularium. Among the Atlantic-Mediterranean species of Rhynchozoon, only R. pseudodigitatum Zabala \& Maluquer, 1988 may possess well-developed oral nodules, but this species is distinguished, among other features, by the suboral avicularium having an uncinate process defining a pseudospiramen.

Other species of Rhynchozoon, as for instance R. haha Hayward, 1988 from the Indo-West Pacific region or R. sexaspinatum Winston \& Woollacott, 2009 from Barbados, may also develop umbos around the orifice, but the former is distinguished from $R$. confusum comb. nov. by its round orifice with a bowl-shaped sinus and knob-like condyles, and the large frontal avicularia; it differs from the latter by its keyhole-shaped orifice, with a large, rounded sinus and very large condyles, and three distinct types of avicularia.

\section{Acknowledgements}

We are grateful to P. Lozouet (MNHN) and to M. Spencer Jones (NHMUK) for their valuable assistance during visits and the loan of material, and to M. Bruni (MOM) for the loan of material. We tender special thanks to L.M. Vieira and J. Winston for communicating unpublished data. Thanks are also due to the staff of the Servizo de Microscopía Electrónica, Universidade de Santiago de Compostela, for the SEM photographs. Finally, two anonymous reviewers provided suggestions to improve the manuscript.

This work was partially supported by the project "Fauna Ibérica: Briozoos II (Familia Cribrilinidae - Familia Watersiporidae)" (CGL2010-22267-C07-02), co-financed by the Ministerio de Economía y Competitividad, Spanish Government, and FEDER. JS thanks the Austrian Science Fund (FWF, Lise Meitner Program, grant M1444-B25) for financial support.

\section{References}

Arístegui Ruiz J. 1984. Briozoos Quilostomados (Ectoprocta, Cheilostomata) de Canarias: Estudio Sistemático, Faunístico y Biogeográfico. PhD Thesis, Universidad de La Laguna, Spain.

Berning B. 2013. New and little-known Cheilostomata (Bryozoa, Gymnolaemata) from the NE Atlantic. European Journal of Taxonomy 44: 1-25. http://dx.doi.org/10.5852/ejt.2013.44 
Bock P. 2014. Escharinidae Tilbrook, 2006. Available from http://bryozoa.net/cheilostomata/ escharinidae/index.html [accessed 1 Oct. 2015].

Busk G. 1856. Zoophytology. Quarterly Journal of Microscopical Science 4: 308-312. Available from http://biodiversitylibrary.org/page/27676524 [accessed 4 Nov. 2015]

Busk G. 1860. Zoophytology. Shetland Polyzoa. Collected by Mr. Barlee. Quarterly Journal of Microscopical Science 8: 143-145. Available from http://biodiversitylibrary.org/page/13768633 [accessed 4 Nov. 2015]

Calvet L. 1906a. Note préliminaire sur les bryozoaires recueillis par les expéditions du Travailleur (1881-1882) et du Talisman (1883). Bulletin du Muséum national d'Histoire naturelle 12: 154-166. Available from http://biodiversitylibrary.org/page/5021333 [accessed 4 Nov. 2015]

Calvet L. 1906b. Deuxième note préliminaire sur les bryozoaires récoltés par les expéditions du Travailleur (1881-1882) et du Talisman (1883). Bulletin du Muséum national d'Histoire naturelle 12: 215-233. Available from http://biodiversitylibrary.org/page/5021396 [accessed 4 Nov. 2015]

Calvet L. 1907. Bryozoaires. Expéditions Scientifiques du "Travailleur" et du "Talisman" pendant les Années 1880-1883 8: 355-495.

Gautier Y.-V. 1962. Recherches écologiques sur les bryozoaires chilostomes en Méditerranée occidentale. Recueil des Travaux de la Station marine d'Endoume 38 (24): 1-434.

Gordon D.P. 2000. Towards a phylogeny of the cheilostomes - Morphological models of frontal wall/ shield evolution. In: Herrera Cubilla A. \& Jackson J.B.C. (eds) Proceedings of the $11^{\text {th }}$ International Bryozoology Association Conference: 17-37. Smithsonian Tropical Research Institute, Balboa, Panama.

Hayward P.J. \& Ryland J.S. 1999. Cheilostomatous Bryozoa. Part 2. Hippothoidea-Celleporoidea. Synopses of the British Fauna, New Series 14: 1-416.

Hincks T. 1880. A History of the British Marine Polyzoa, 2 vols. van Voorst, London.

d'Hondt J.-L. 1974. Bryozoaires récoltés par la « Thalassa » dans le Golfe de Gascogne (Campagnes de 1968 à 1972). Cahiers de Biologie Marine 15: 27-50.

d'Hondt J.-L. 1975. Bryozoaires Cténostomes et Cheilostomes (Cribrimorphes et Escharellidae exceptés) provenant des dragages de la campagne océanographique Biaçores du "Jean Charcot". Bulletin du Muséum national d'Histoire naturelle, $3^{\text {rd }}$ Series 299: 553-600.

ICZN. 1999. International Code of Zoological Nomenclature. International Trust for Zoological Nomenclature, London.

Jullien J. 1882. Dragages du Travailleur. Bryozoaires. Espèces draguées dans 1'Océan Atlantique en 1881. Espèces nouvelles ou incomplètement décrites. Extrait du Bulletin de la Société Zoologique de France 7: 1-33. Available from http://dx.doi.org/10.5962/bhl.title.4721 [accessed 4 Nov. 2015]

Jullien J. 1883. Dragages du Travailleur. Bryozoaires. Espèces draguées dans l'Océan Atlantique en 1881. (Séance du 26 décembre 1882). Espèces nouvelles ou incomplètement décrites. Bulletin de la Société Zoologique de France [1882] 7: 497-534. Available from http://biodiversitylibrary.org/ page/11314295 [accessed 4 Nov. 2015]

Jullien J. \& Calvet L. 1903. Bryozoaires provenant des campagnes de l'Hirondelle (1886-1888). Résultats des Campagnes Scientifiques du Prince de Monaco 23: 1-188. Available from http://biodiversitylibrary. org/page/2147090 [accessed 4 Nov. 2015]

Marcus E. 1940. Mosdyr (Bryozoa eller Polyzoa). Danmarks Fauna 46: 1-401.

Norman A.M. 1869. Shetland final dredging report. Part II. On the Crustacea, Tunicata, Polyzoa, Echinodermata, Actinozoa, Hydrozoa, and Porifera. Report of the British Association for the Advancement 
of Science for 1868: 247-336. Available from http://biodiversitylibrary.org/page/29387922 [accessed 4 Nov. 2015]

Ostrovsky A.N. 2013. Evolution of Sexual Reproduction in Marine Invertebrates: Example of Gymnolaemate Bryozoans. Springer, Dordrecht. Available from http://link.springer.com/book/10.1007 \%2F978-94-007-7146-8 [accessed 4 Nov. 2015]

Ostrovsky A.N., Nielsen C., Vávra N. \& Yagunova E.B. 2009. Diversity of brood chambers in calloporid bryozoans (Gymnolaemata, Cheilostomata): comparative anatomy and evolutionary trends. Zoomorphology 128 (1): 13-35. http://dx.doi.org/10.1007/s00435-008-0070-8

Reverter-Gil O \& Fernández-Pulpeiro E. 1999. Some little-known species of Bryozoa described by J. Jullien. Journal of Natural History 33 (9): 1403-1418. http://dx.doi.org/10.1080/002229399299941

Reverter-Gil O. \& Fernández-Pulpeiro E. 2001. Inventario y cartografia de los briozoos marinos de Galicia (N.O. de España). Monografias de Nova Acta Cientifica Compostelana, Serie Bioloxía 1: 1-243.

Reverter-Gil O. \& Fernández-Pulpeiro E. 2005. A new genus of cyclostome bryozoan from the European Atlantic coast. Journal of Natural History 39 (25): 2379-2387. http://dx.doi. org/10.1080/00222930400023743

Reverter-Gil O., Berning B. \& Souto J. 2015. Diversity and systematics of Schizomavella species (Bryozoa: Bitectiporidae) from the bathyal NE Atlantic. PLoS ONE 10 (10): e0139084. http://dx.doi. org/10.1371/journal.pone.0139084

Reverter-Gil O., Souto J. \& Fernández-Pulpeiro E. 2011. Revision of the genus Crepis Jullien (Bryozoa: Cheilostomata) with description of a new genus and family and notes on Chlidoniidae. Zootaxa 2993: $1-22$.

Ryland J.S. 1969. A nomenclatural index to "A History of the British Marine Polyzoa" by T. Hincks (1880). Bulletin of the British Museum (Natural History), Zoology 17: 207-260. Available from http:// biodiversitylibrary.org/page/2350878 [accessed 4 Nov. 2015]

Souto J., Fernández-Pulpeiro E. \& Reverter-Gil O. 2007. Bryozoans of the expeditions of the Pourquoi Pas? in the English Channel and around the British Isles between 1914 and 1930. Cahiers de Biologie Marine 48: 361-372.

Souto J., Reverter-Gil O. \& Fernández-Pulpeiro E. 2011. Redescription of some bryozoan species originally described by J. Jullien from Iberian waters. Zootaxa 2827: 31-53.

Tilbrook K.J. 2006. Cheilostomatous Bryozoa from the Solomon Islands. Santa Barbara Museum of Natural History Monographs 4: 1-386.

Manuscript received: 14 August 2015

Manuscript accepted: 21 October 2015

Published on: 30 November 2015

Topic editor: Rudy Jocqué

Desk editor: Danny Eibye-Jacobsen

Printed versions of all papers are also deposited in the libraries of the institutes that are members of the EJT consortium: Muséum national d'Histoire naturelle, Paris, France; Botanic Garden Meise, Belgium; Royal Museum for Central Africa, Tervuren, Belgium; Natural History Museum, London, United Kingdom; Royal Belgian Institute of Natural Sciences, Brussels, Belgium; Natural History Museum of Denmark, Copenhagen, Denmark. 